\title{
Oral Corrective Feedback: Exploring The Relationship Between Teacher's Strategy and Students' Willingness to Communicate
}

\author{
Lailatus Sa'adah ${ }^{1}$, Joko Nurkamto ${ }^{2}$, Suparno ${ }^{3}$ \\ Sebelas Maret University

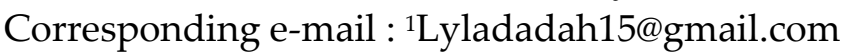

\begin{abstract}
Corrective feedback has become a big issue in second language acquisition. Its effectiveness when implemented in the class is still the subject of debate. Moreover, its impact on second language learners' performance is also a topic of discussion. Recently, there has been a growing interest in the role of corrective feedback as a research topic in EFL context. Most researches showed that corrective feedback has a positive effect on EFL learners. Although there has been a growing research concern on the effectiveness of oral corrective feedback, its impact and its application in EFL classroom setting, limited studies examined the relationship between teachers' corrective feedback and students' willingness to communicate. Therefore, this case study explores how oral corrective feedback is implemented in the class and its effect on the students' willingness to communicate. For this purpose, interviews and observations were used to collect data from a teacher and tenth grade students of senior high school in the academic year 2016/2017. The findings showed that there are three types of oral corrective feedback found in the class: explicit correction feedback, metalinguistic feedback, and clarification request feedback. Moreover, the students frequently make phonological errors and semantic errors while speaking. In regard to the students' uptake, acknowledgement, repetition, off-target, and peer-repair are mostly found from the teacher and students interaction. The students also insist that the teacher's oral corrective feedback does not disturb teacher and students classroom interaction.
\end{abstract}

Keyword: oral corrective feedback, willingness to communicate, case study

\section{INTRODUCTION}

Recently, corrective feedback becomes a controversial issue in second language acquisition research (Brown, 2007, p. 273; Martinez, 2013; Rezaei, Mozaffari, \& Hatef, 2011, p. 21). Its effectiveness while being implemented in the class become the subject of debate (Martinez, 2013; Chen, Nassaji, \& Liu, 2016). In spite of good potential in implementing corrective feedback in the class, most researches come up with divergent results. Some researchers found out about its effectiveness (chu, 2011; Leontjev, 2014), while the others showed the contrast (Naziri \& Haghverdi, 2014). Moreover, its impact on second language learners' performance is also a topic of discussion (Ahyan, Arikan, \& Akbarov, 2011). According to Ellis (2013), "correcting students may be deemed necessary but it is also seen as potentially dangerous because it can damage learners' receptivity to learning" (p. 3). In this respect, some scholars pointed out their point of view. Harmer (2007, p. 142) claims that it is a need to point out and correct the students' mistakes which involve accuracy work due to its advantages that lead to the complete accuracy. However, Harmer (2007, p. 143) also believes that it is no need an interruption on students' mistakes in 
grammar, lexical, or pronunciation errors during communicative activities because such circumstances can raise students stress level and stop the acquisition. On the other hand, Brown (2007) proposes that "too much negative cognitive feedback leads learners to decrease their attempts to communicate, while too much positive cognitive feedback caused the errors become uncorrected" (p. 274). Moreover, Truscott (1999, as cited in Martinez, 2013, p. 266) believes that feedback on error does not actually work because corrective feedback may cause embarrassment, anger, inhibition, and feeling inferiority among learners.

Researchers such as Zohrabi \& Ehsani (2014) investigated the role of implicit \& explicit corrective feedback in Persian speaking EFL learners' awareness of and accuracy in English grammar. Moreover, the result emphasizes the importance of providing corrective feedback in EFL setting, because through corrective feedback the learners can improve their language proficiency. Another study by Chu (2011) on corrective feedback found that corrective feedback has a positive effect on improving oral English accuracy of English-Majors college students, but the effectiveness for different levels of learner are different. Considering the result of these two researchers, it can be interfered that providing corrective feedback in the class is important and it does make great effect on oral production. Additionally, Macintyre and Burns (2007, p. 57, cited in Rashidi, Basiro, \& Motlaq, 2016) mention corrective feedbacks both as something that increases and as something that decreases students' willingness to communicate, depending on whether it is expected and how it is offered. In line with this, Brown (2007) also believes that "too much negative feedback - a barrage of interruptions, corrections, and overt attention to malformations - often lead learners to shut off their attempts at communication" (p. 274). Both statements lead to the assumption that students' willingness to communicate is a result from the corrective feedback implemented by teacher in the class. Therefore, investigating the relationship between teachers' corrective feedback and students' willingness to communicate is a need. Despite the pros and conts on the effectiveness of corrective feedback in several experimental studies, most of them merely investigated its effectiveness on accuracy (Chu, 2011) and pronunciation (Naziri \& Haghverdi, 2014). In addition, less of them investigate what actually happened behind those issues. Another experimental study conducted by Rashidi et al. (2016) investigated the effect of different types of corrective feedback on the students' willingness to communicate and its relationship with gender. Moreover, the result showed that there was a significant effect of types of corrective feedback on the students' willingness to communicate, but having no interaction with gender. Therefore, this phenomenon raised the researcher interest to explore the types of teacher's oral corrective feedback and its' influence on the students' willingness to communicate in the class.

Based on the discussion above, the researcher would like to conduct a case study on the implementation of oral corrective feedback and its relationship with the students' willingness to communicate. This research will involve tenth grade students of private school in Surakarta, Indonesia who are involved in conversation class that is used to communicate between one and another and often received teachers' oral corrective feedbacks. In this school, the students have different educational background before enrolls to this high school, so that, their competence in English are also different. 
The researcher found that there are some students who have already been familiar with English, but some of them are not. However, most of them are shy and sometimes worry to participate in conversation class. Meanwhile, from the interview, the researcher obtained some information that students are mostly shy and worry to participate in conversation class, although this situation does not last too long. The following month the students become active in this class, and sometimes join debate program and speech contest. This case is unique to investigate, as we know that corrective feedback has been investigated annually in terms of correcting grammar and writing, and only a few researchers investigated its role on oral production which relate to students' willingness to communicate. Therefore, this research will explore how oral corrective feedback is implemented in the class, the focus of teacher in correcting students' error, teachers and students' perception toward its implementation and its effect on the students' willingness to communicate. This research will use the views about oral corrective feedback from Lyster and Ranta's work (1997). This grand theory is chosen because Lyster and Ranta's work involve learners' oral production and has been widely used in many studies (Chu, 2011; Roothooft, 2014; Pfanner, 2015; Yang, 2016) due to its comprehensiveness in classifying the taxonomy of oral corrective feedback (Agudo, 2012, p. 125)

\section{Review of Related Literature}

a. The definition of corrective feedback

Corrective feedback has been defined differently yet very similar. One of the earliest definition is that of Chaudron (1997, cited in Mendez \& Cruz, 2012, p. 64), who considers it as "any reaction of the teacher which clearly transforms, disapprovingly refers to, or demands improvement of the learner utterance". Moreover, Ellis, Loewen \& Arlam (2006) stated that, "Corrective feedback takes the form of responses to learner utterances that contain error. The responses can consist of (a) an indication that an error has been committed, (b) provision of the correct target language form, or (c) meta-linguistic information about the nature of error, or any combination of these" (p. 340). In addition, Li (2013, p.2) states that corrective feedback refers to responses to learners' production errors, the purpose of which is, or is perceived as, remedial, regardless of whatever the errors cause communication problems. Considering those definitions provided by experts above, it can be understood that corrective feedback is an action given by the teacher to eliminate errors made by the students or learners in producing the target language.

b. Types of oral corrective feedback

According to Lyster and Ranta (1997, cited in Yang, 2016, p. 76), oral corrective feedback is classified into six classification, they are: Explicit correction, Recasts, Elicitation, Metalinguistic Feedback, Clarification requests, and Repetition. 1) Explicit correction: teachers supply the correct form and clearly indicate that what the students say is incorrect (Chu, 2011, p. 455). 2) Recast: teacher implicitly reformulates all or part of the students' utterance (Chu, 2011, p. 455). The degree of implicitness of the recast can be reduced by rephrasing only a part of the utterance, or adding emphasis on the corrected element without indication that the utterance was ill-formed (Taipale, 2012, p. 37). 3) Elicitation: teacher directly elicits by asking questions or by pausing to allow students to complete teacher's 
utterance, or asking students to reformulate their utterance (Chu, 2011, p. 455). 4) Metalinguistic feedback: teacher emphasizes on explicit explanation of forms (Yang, 2016, p. 76). 5) Clarification request: teacher's request for further information from a student about a previous utterance (Chu, 2011, p. 455) or teacher ask student to reformulate their utterances which are hard to understand (Yang, 2016, p. 455). 6) Repetition: teacher repeats the student's ill-formed utterances, adjusting intonation to highlight the error (Chu, 2011, p. 455).

c. Types of error

Errors have been categorized by Mackey, Gass, \& McDonough (2000) and Nishita (2004) as cited by Mendez and Cruz (2012) into as follows: (1) Morphosyntactic error: learner incorrectly use word order, tense, conjunction, and articles., Phonological error: learners mispronounce words., (3) Lexical error: learners use vocabulary inappropriately or they code-switch to their first language because of their lack of lexical knowledge., (4) Semantic and pragmatic error: the misunderstanding of a learner's utterance, even if there are no grammatical, lexical or phonological errors.

\section{d. Learner Uptake}

Corrective feedback is usually followed by uptake (Ellis, 2012, p.178). Ellis (2012, p. 178) states that uptake is a term that has been used to refer to a discourse move, where learners respond to information they have received about some linguistic problems they have experienced. In other words, uptake is students' respond toward the corrective feedback given by teacher. Students' uptake can be in form of body movement or the other types of uptake move. According to Lyster \& Ranta (1997, cited in Ellis, 2012, p. 179), there are two kinds of uptake move. They are: Repair and Needs repair. Repair refers to the accurate reformulation of the error produced by the student. In other words, the student is able to correct the error by using the information in the feedback given by the teacher (Taipale, 2012, p. 44). According to Lyster and Ranta (1997, cited in Ellis, 2012, p. 179) types of repair uptake are repetition, incorporation, selfrepair, and peer-repair. On the other hand, needs repair refers to the situation where the students still need of repair. Meanwhile types of needs repair uptake are acknowledgement, same error, different error, off-target, hesitation, and partial repair.

\section{e. How to Deliver Oral Corrective Feedback}

"Corrective feedback can be provided immediately after the error has been made, or it can be delayed until later, after the communicative activity the learners are engaged in is finished" (Mendez \& Cruz, 2012, p. 67). Moreover, the frequency of delivering feedback also substantial. If the corrective feedback is being given too much, it will bring negative effect on the students' attitude and performance (Mendez \& Cruz, 2012, p. 68). Meanwhile, if the corrective feedback is being given less, it will be perceived as a hindrance for efficient and effective language learning by learners (Mendez \& Cruz, 2012, p. 68). Therefore, finding the balance between the issues is very crucial for teacher. The way teacher gives corrective feedback are not always the same among learners. This is in line with Agudo's (2013, p. 269) statement which relate to the flexibility of providing corrective feedback to the learner's cognitive and affective needs. Agudo (2013, p. 269) says that teacher should correct the students' error individually because all students cannot be treated in the same way. However, 
this technique itself involves an enormous challenge for teachers and it becomes a difficult task for teacher.

\section{f. Definition of Willingness to Communicate}

According to MacIntyre et al (1998, cited in Vongsila \& Reinders, 2016, p. 2), willingness to communicate is a readiness to enter into the discourse at a particular time with a specific person or persons, using a second language. In line with this, Dornyei \& Ryan (2015, p. 180) asserted that willingness to communicate describes how a number of factors interact to influence an individual's likelihood of initiating communication in a specific situation. Moreover, in turn, Ellis (2012, p. 321) pointed out that willingness to communicate can also be viewed as a trait or a situational variable, influenced by specific instructional factors. In short, willingness to communicate is defined as individual's readiness in initiating a communication in a specific situation with a specific person and also by specific factors.

\section{METHOD}

a. Research Context

This study conducted at one of the private schools in Surakarta. The researcher interested in conducting the research in this school because the curriculum in which English is taught does not only focus on the written form and students' comprehension but also focus on oral production. Therefore, the school makes an extra class in order to develop students' oral production by commanding their students to join conversation class.

\section{Research Design}

A case study chosen in this study due to several reasons. The first, the objective of this qualitative study is to explore and describe the phenomenon which happens in the real-life context. Specifically, the phenomenon of this study is the implementation of oral-corrective feedback by the teacher in teaching speaking. Moreover, by using case study, the researcher can get details and accurate information about the ways the teacher gives oral-corrective feedback to the students in the class, the ways students apprehend the oral-corrective feedback from the lecturer, and the compatibility between the implementation of oral corrective feedback in the class and the theory of it. And finally, by conducting a case study, the researcher can explore situations happen in the class which have not been revealed yet.

b. Source of Data

There are two kinds of data sources used in this study, informants and events. The informant of this study were an English teacher and three students of tenth grade of private school in Surakarta. In addition, they were selected through purposive sampling. The events include the process of the implementation of oral corrective feedback by the teacher in teaching speaking in conversation class. Another event is that the activity of learning English speaking skill which will be done by the students in the class.

\section{c. Data Collection Technique}

In this study, the researcher used two kinds of techniques of collecting the data, interview and observation. The researcher made an interview with three students and one teacher involved in English conversation class and chosen by using purposive sampling. The observation data were obtained through the observation that the researcher did by joining the English conversation class three times once in a week. The researcher made field note and voice recording while doing observation in the class.

d. Validily of Data 
In this study, the researcher used data triangulation, member checking, and external audit. Data triangulation is used in order to support the finding of case study by more than a single source of evidence (Yin, 2014, p. 121). Another strategy is member checking. Lincoln \& Guba (1985, cited in Creswell, 2007, p. 208) stated that member checking is the most critical technique for establishing credibility. In this strategies, the researcher invites the participants' views of the credibility of the findings which involves taking data, analysis, interpretations, and conclusions so that they can judge the credibility of the data (Creswell, 2007, p. 208). The last strategy is auditing or external audit. In this strategy, "the researcher asked a person outside the research to conduct a thorough review of the study and report back, in writing, the strengths and weaknesses of the research" (Creswell, 2012, p. 260).

e. Data Analysis Technique

In this study, the researcher used logic model technique based on Yin (2014, p. 155). According to Yin (2014, p. 155), logic models involve a repeated cause-andeffect sequence of events. This technique is also useful for case study evaluations (Yin, 2014, p. 155). This technique is used to match the observed events to theoretically predicted events which is in line with the purpose of this study. Relate to this, this study used the following procedures in analyzing the data. First, the interview and observation data were analyzed based on the category of each problem. The data which were obtained from interview are compared with one another. After the interview data were found, they continually are verified from the observation data. In this case, the researcher affirmed or rejected or modified the data. The last step, the researcher made an assumption and explained the reason of the outcome assumption. The sequence of error treatment started when the students utter some erroneous utterance. It was followed by the teacher's decision whether or not she provides the corrective feedback. If she did, the researcher classified the feedbacks given by the teacher into explicit correction, recast, elicitation, metalinguistic feedback, repetition, and clarification request. Besides the teacher's feedback, the researcher also noted whether or not the students respond to the feedback. If there is a feedback up taken by the students, the researcher noted whether or not the students can repair the error by themselves or the teacher did the correction.

\section{RESULT AND DISCUSSION}

\section{A. RESULT}

a. Types of Oral Corrective Feedback Used in Conversation Class

\section{Explicit Correction}

In the conversation class, teacher often used explicit correction as a feedback for the students. Explicit correction occurs when the teacher both gives the correct form and additionally points out that the students' utterance was incorrect (Taipale, 2012, p. 38). In this case, the teacher points out that the students' utterance was incorrect, so she gives the correct form of the error. It can be seen from the conversation between teacher and students in the class in the following example:

\section{Example 1}

Students : poor you

(phonological error)

Teacher : poor you, you have to put intonation too. Poor you

(explicit correction)

Students

: poor you (repetition)

In this example, the class discussed about the expression used in daily activity. The teacher is asking the 
students to read aloud the expression that had been studied. while the students said poor you without intonation then the teacher directly corrected their pronunciation errors into the proper one. In addition, the teacher also gives advice to emphasize the intonation of the expression poor you. After that all of the students directly correct their pronunciation. A student said, "If I made a mistake in pronunciation, teacher just directly told me the right way to say it. Just that." (Interview/S3). In this regard, some informations were collected after having interview with S1, S2, and S3. S3 said that when she had a problem with pronunciation in the class, the teacher directly corrected her mistake by saying the right way to pronounce it. Moreover, she also said that the teacher would not use a complicated way to explain the mistake and just corrected the mistake. This is in line with the statements stated by $S^{1}$ and $S^{2}$.

\section{Metalinguistic}

As to metalinguistic feedback, the way teacher gives the feedback is based on their linguistic knowledge. In this conversation class, the teacher also gives metalinguistic feedback to the students. Metalinguistic feedback occurs when the teacher emphasizes on explicit explanation of forms, such as comments, information or question (Yang, 2016, p. 76; Taipale, 2012, p. 40). Example 2 is an instance of metalinguistic feedback where the teacher gives additional information provided on a phonological error:

Example 2

Students : Leather your bathroom (phonological error)

Teacher : Oke. This is .. there is example, the difference between UK and US, can you hear it? Pay attention. Ini yang UK "lather", ini yang US "lether" okey? (metalinguistic feedback)

Students : Yes miss. Leather (they said that in both UK and US) (acknowledgement)

Here, the teacher asked the students to read leather your bathroom, however, the students did not pronounce it correctly. Then the teacher said "ok this is ... there is example, the different between UK and US, can you hear it, pay attention, this one is UK leather, and this one is US leather". In this situation, the teacher gave a metalinguistic feedback by giving an authentic example by listening to a recording of how to pronounce leather for both british and american accent. The students finally can gain a knowledge of how to pronounce leather in a right way.

Another evidence was found in the interview. S1, S2, and S3 confirmed that the teacher once gave the metalinguistic feedback. On the other hand, the teacher also confirmed that she is constantly gives metalinguistic feedback to the students in order to make them learn from their mistakes. Considering all those cases, it can be interpreted that metalinguistic feedback is one of the types of oral corrective feedback which is usually used by the teacher in conversation class.

\section{Clarification Request}

Different from metalinguistic feedback and explicit correction, in this clarification request, the teacher is not directly correcting the students by giving details explanation but questioning them. In this study, the researcher found that clarification request feedback is also used by the teacher in order to correct students' 
mistakes made. Below is an example of clarification request found in the present data:

Example 3

Teacher : what is the meaning of take it easy?

Students : dibikin indah aja (L2-L1 translation error)

Teacher : are you sure? (clarification request)

Students : yes mam. (acknowledgement)

In example 3, the students were asked by the teacher to find the meaning of take it easy in Indonesian language. The students directly answered "dibikin indah aja", while the teacher said "are you sure?", and "yes mam" said the students. In this case, the teacher asks for clarification by saying are you sure? to the students. It is done by the teacher in order to know whether they are certain with their answer. The teacher only gives a clue that the answer might be wrong. This condition in line with the statement from S1, who said that the teacher often gives them clarification request and she assumes that this might happen because the teacher wants to increase the students' self-confidence. As well as S1's statement, the teacher approved that asking students' opinion is important to make them to think critically.

\section{b. Types of Error Found in Conversation Class}

In the conversation class, students are sometimes making some errors while speaking. Apparently, their errors in speaking vary from one students to another. In this study, the researcher found several types of errors which always occur in the conversation class. The first error deals with phonological errors. Phonological errors refers to errors in pronunciation. These errors are commonly caused by the differences between two languages and their sound systems (Taipale, 2012, p. 33). The conversation between teacher and students in the $1^{\text {st }}$ observation below shows an instance of a phonological error:

Example 4

Teacher : Go clean up yourself

Students : Go clean up yourself (phonological error)

Teacher : So, clean and up is should be clean-up, don't say go clean up yourself, but clean-up yourself. Oke once more. (Explicit correction)

Students : Go clean-up yourself. (repitition)

In Example 4, the teacher asks the students to read aloud about some expressions used in daily life. They are asked to follow the teacher utterances. However, some students still mispronounce the expression of go clean up yourself. The students utter it with weak stress, so that, the teacher corrected their utterances because she found it inappropriate. The teacher then provides feedback by saying what the students said is incorrect and gives the correct pronunciation along with some brief explanation. Another type of error found is L2-L1 translation errors. This type of error is not included into the types of errors proposed by Mackey, Gass, \& McDonough (2000) and Nishita (2004). This type of error cannot be categorized into morphosyntactic, phonological, lexical, semantic and pragmatic error. Therefore, Taipale (2012) who analyzed oral errors in EFL setting made a category of its own and classified there as L2-L1 translation error. The decision of using this category is based on the findings obtained in the field. L2-L1 translation errors to refer to the inaccurate translation of the English words made by the students. Example 5 is an instance where the students do a translation error:

Example 5

Teacher : what is the meaning of go clean up yourself?

Student A : segera bersihkan dirimu (L2-L1 translation error) 
Student B : Bersihkan dirimu (L2-L1 translation error)

Teacher : No one right here, oke, if you write "segera bersihkan dirimu", it can be "go, tidy up yourself", but go clean up your self means "cepetlah mandi sana" (metalinguistic feedback)

Students : ooooooo

(acknowledgement)

The first error deals with the misinterpretation about the meaning of $g o$ clean up yourself in Indonesian. While the teacher and students are having a conversation class, the students are asked to find the meaning of go clean up yourself. The students translate the sentence in difficult ways which convey difficult meaning: segera bersihkan dirimu; cepat bersihkan dirimu; and so forth. No one gives the right answer expected by the teacher. After a long discussion, then, the teacher gave both explanation and answer to the students.

\section{c. Types of Students' Uptakes Found in Conversation Class}

When the teacher gives the corrective feedback to the students, sometimes it leads the students to response or react to the feedback in different ways, which is called students' uptake. In this research, the researcher investigated the kind of uptake found in conversation class. As it as already proposed in the previous chapter that students' uptakes are vary, such as; repetition, incorporation, selfrepair, peer-repair, acknowledgement, same error, different error, off-target, hesitation, and partial repair. The data taken from the classroom observation showed that there are four types of students' uptake found in conversation class. The most dominant students' uptake found is acknowledgement. This type of students' uptake is relates to the students' acceptance or rejection of the feedback given by the teacher. Illustration of acknowledgement can be found in example 2, 3, and 5 above. The second type of students' uptake is repetition. The teacher provides a feedback which contains the correct form of students' illformed message and then repeated by the students. In this research, the researcher found repetition in some pronunciation errors. The example is the conversation between teacher and students which can be found in example 1. In addition, offtarget type also occurs in the conversation class. In this type, the students respond by circumventing the teacher's linguistic focus. Somehow, the students ask for further explanation related to the teacher feedback because the students assumed that what they said is correct. The example is the conversation between teacher and students in the 3rd observation:

Example 6

Teacher : No one right here, oke, if you write "segera bersihkan dirimu", it can be "go, tidy up yourself", but go clean up yourself means "cepatlah mandi sana".

Students : ooooooooo

(acknowledgement)

Student B : Kok cepetan mandi? (offtarget)

In this situation, the class is talking about the translation of some expressions used in daily life. The teacher asked the students to translate "go clean up yourself" into Indonesian. A student replies by writing segera bersihkan dirimu, which according to the teacher does not imply the correct meaning of "go clean up yourself". As a result, she gives the correct translation and explained the situation to the students. Most students understand the teacher answer and assumed that the teacher feedback is correct. On the contrary, one of the students, still cannot get what the teacher means. The last type of students' uptake which is found is peer-repair. In this case, the students other who do not produce the error, corrected the error in 
response to teacher feedback. This happens because of the inequality of students' understanding of the material given. The example is the conversation between teacher and students in the 3rd observation:

Example 7

Teacher : save it or change it?

Student A: apa miss? Save it or chicit?

Teacher : change it

Student A: ....

Student B : change it change it

In this situation, the teacher and the students have been talking about the task. The students are asked to translate some expression in English into Indonesian. The teacher then asks the students whether they agree with the answer or want to change the answer. Therefore, the teacher said "save it or change it". However, one of the students misheard the word change. Although the teacher has already given the feedback. Student A still cannot catch the word. So that, the student $B$ tries to give the oral feedback also to the student A.

\section{d. The teacher's way in correcting students' error}

Teacher insist that She would not interrupt the students chance to speak while conversation class is held, because the most important things is students' willingness to speak in the class and how they can communicate fluently and confidently. Moreover, in correcting the students mistakes or errors, The teacher prefers to wait until the students finish their words in order to not disturb their concentration. However, when the students make pronunciation errors, she prefers to give a direct feedback right after the students' mispronounce the word. In line with this, the teacher said that she prefers to use immediate correction because she wants the students have a critical thinking so that the teacher knows whether or not the students understand the material which has already given to them. Unlike immediate correction, delayed correction is rarely used by the teacher. She never wait for the class period to end just to discuss students errors in detail.

\section{e. The Effect of Teacher's Oral Corrective Feedback on the Students' Willingness to Communicate.}

It is widely believed that the teacher's correction toward the students' mistakes or errors sometimes affect to the students' willingness to communicate. Therefore, investigating this case is also important for academician. In this study, the researcher gave interview to both teacher and students in order to gain some significant information which relate to this, and also observed the process of teaching learning activity. Based on the data obtained, teacher's oral corrective feedback gives a positive effect on the students' willingness to communicate. The teacher insists that the use of oral corrective feedback is not disturbing the student's activity in the class. Although there are some students who are quite shy to join the conversation at first, as long as the teaching learning continue, all of the students become active in conversation class. Moreover, all of the students keep active in the class despite the fact that the teacher keeps giving corrective feedback in pronunciation, grammar, and so forth. In line with the teacher statements, the students proposed that the teacher's feedback does not disrupt the process of teaching and learning in conversation class. And they acknowledge that teacher's oral correction is an ordinary thing that usually happens in the class. And they feel so open to be corrected by the teacher although when they are in the middle of delivering the idea in the class. It can be interpreted that the teacher's feedback does not make them shy or reluctant to join the conversation class.

\section{B. DISCUSSION}

In this section, the focus will be the discussion of both research findings and 
the findings in other researcher. The researcher compares both findings in order to find the similarities and differences. In summary, the findings of this research showed that there are three types of oral corrective feedback mostly used by the teacher in conversation class, they are; explicit correction, metalinguistic, and clarification request. Unlike the findings of this study, the previous studies showed that all types of oral corrective feedback were thought to be provided to an equal measure in the class. However, recasts are considered to be the most common type used in the class (Dilans, 2015). Meanwhile, in this present study no recast was found. Based on the observation, the teacher tends to use metalinguistic feedback in order to cope with the students' errors. The reason metalinguistic feedback was used in most conversation class because the teacher wants to make the students learn from their mistakes or errors. Moreover, the findings showed that metalinguistic is one of the common type of oral corrective feedback used in the class. This finding correspond the previous study which showed that learners preferred to have a metalinguistic feedback rather than others for all error types (Yang, 2016).

The findings also told that the students frequently made phonological and semantic errors. This result partly echoes the studies of Eini, Gorjian, and Pazhakh (2013) who said that the students showed lack of improvement in the content and structure of their speech in their study. Moreover, Dilans (2015) found that feedback was mainly provided in response to morphological, lexical, and phonological errors. However, in better context, Yang (2016) stated that explicit correction and recast were endorsed for phonological, lexical and grammatical errors.
In terms of the students' uptake, there are three types of students' uptake found in this research, they are; acknowledgement, repetition, and offtarget. However, the data obtained from students' interview stated that hesitation also frequently happened. Slightly different from the actual situation, students are more definite about what they really want to utter. Hesitation, a sort of uptake, was not found in the data. In Taipale's study (2012, pp. 43-47), most of the types of uptake were found, such as; repetition, incorporation, self-repair, peerrepair, acknowledgement, same error, different error, partial repair, and hesitation. However, off target is the only uptake type which could not be found in his study.

Moreover, in this research, it was also found that the teacher prefers to use immediate correction rather than delayed correction. This findings are supported by the work of Shabani (2016, p. 108) who said that the effect of Immediate type of error correction was larger than delayed correction in improving learner's accuracy on their oral production. The reason of that choice is that the teacher wants to invite the students to be more critical so that the teacher knows whether the students understand the material. Moreover, the teacher also insist that guarding students from errors is the teacher's responsibility. Furthermore, the teacher did not give feedback to all errors. The time spent on giving error correction depends on the focus of the teaching learning activity. For instance, if the conversation class that day focuses on grammar, the teacher mostly focuses on correcting students' grammar errors.

In addition, it is also found that the teacher's oral corrective feedback gives a positive effect on the students' willingness to communicate. The teacher insists that 
the use of oral corrective feedback does not disturb the student's activity in the class. In line with this, Eini, Gorjian, and Pazhakh (2013, p. 813) said that teacher corrective feedback and peer corrective feedback had a beneficial effect on students' ability in post speaking activity. It can develop students' critical thinking, learner autonomy and social interaction among students. Ahmad, Saeed, and Salam (2013, p. 39) found that corrective feedback improve students' learning. In the same way, students who get corrective feedback from their teacher perform better in the examination. It can enhance students' confidence, self-esteem and also improves their communication and writing skills.

\section{CONCLUSION}

This study provides an understanding of the implementation of oral corrective feedback used in conversation class. The findings show that the teacher uses a range of oral corrective feedback types. Explicit correction, Metalinguistic, and clarification request were the types of oral corrective feedback found in this study. Metalinguistic feedback is the most dominant type of oral corrective feedback used by the teacher in conversation class. The study also reveals that phonological errors and semantic errors were mostly discovered from the conversation between teacher and students in the class. In regard to the students' uptake, it shows that there are four types of students' uptake found in conversation class. They are acknowledgment, repetition, off-target, and peer-repair. Finally, teacher's oral corrective feedbacks do not cause students' unwillingness to communicate in the conversation class. The students insisted that the teacher's feedback is not a certain case which hinders the students to communicate in the class.

\section{REFERENCES}

Ahmad, I., Saeed, M., \& Salam, M. (2013). Effect of Corrective Feedback on Academic Achievements of Students: Case of Government Secondary Schools in Pakistan. International Journal of Science and Research, 2(1). Retrived from www.ijsr.net

Agudo, J. 2012. Investigating Spanish EFL Students' Belief and Preferences Regarding the Effectiveness of Corrective Feedback. International Journal of Humanities and Social Science, 2 (19).

Ahyan, U., Arikan, M., \& Akbarov, A. (2011). Positive Impact of Corrective Feedback in SLA. 1st International Conference on Foreign Language Teaching and Applied Linguistics. Retrieved from eprints.ibu.edu.ba

Ary, et al. (2010). Introduction to Research in Education. Belmont: Wadsworth.

Brown, D. H. (2007). Principles of Language Learning and Teaching. New York: Pearson Education Inc.

Chen, S., Nassaji, H., \& Liu, O. (2016). EFL Learners' Perceptions and Preferences Of Written Corrective Feedback: A Case Study Of University Students From Mainland China. Asian-Pacific Journal of Second and Foreign Language Education, 1(5). Retrieved from link.springer.com/article/10.1186/s4 0862-016-0010-y.

Chu, R. (2011). Effects of Teacher's Corrective Feedback on Accuracy in the Oral English of EnglishMajors College Students. Theory and Practice in Language Studies, 1 (5). Retrieved from www.academypublication.com/iss ues/past/tpls/vol01/05/03.pdf. 
Creswell, J. W. (2007). Qualitative Inquiry \& Research Design: Choosing Among Five Approaches (2nd). London: SAGE Publications, Inc.

Creswell, J. W. (2014). Educational Research: Planning, Conducting and Evaluating Quantitative and Qualitative Research (4th). London: SAGE Publications, Inc.

Dilans, G. (2015). Corrective feedback in L2 Latvian classrooms: Teacher perceptions versus the observed actualities practice. Language Teaching Research, 1-19. DOI: 10.1177/1362168815584454

Dornyei, Z., \& Ryan, S. (2015). The Psychology of the Language Learner Revisited. New York: Routledge.

Eini, M., Gorjian, B., \& Pazhakh, A. (2013). The Effect of Corrective Feedback Modalities on Second Language Post-Speaking Activities among Iranian Pre-intermediate EFL Learners. Advance in Asian Social Science, 4 (2). Retrieved from www.worldsciencepublisher.org.

Ellis, R. (2012). Language Teaching Research and Language Pedagogy. West Sussex: John Wiley \& Sons, Inc.

Ellis, R., Loewen, S., \& Erlam, R. (2006). Implicit and Explicit Corrective Feedback and the Acquisition of L2 Grammar. Studies of Second Language Acquisition, 28, 339-368.

Ellis, R. (2013). Corrective Feedback in Teacher Guides and SLA. Iranian Journal of Language Teaching Research, 1 (3). Retrieved from www.urmia.ac.ir/ijltr.

Harmer, J. (2001). The Practice of English Language Teaching (3rd ed). Essex, UK: Pearson Education.
Harmer, J. (2007). The Practice of English Language Teaching (4th ed). Essex, UK: Pearson Education.

Li, S. (2013). The Interface between Feedback Type, L2 Proficiency, and the Nature of the Linguistic Target. Language Teaching Research, $0(0)$ 1-24. Retrieved from Itr.sagepub.com

Macintyre, P. D. (2007). Willingness to Communicate in the Second Language: Understanding the Decision to Speak as A Volitional Process. The modern language journal, 91 (4), 564-576. doi: 10.1111/j.1540-4781.2007.00623.x

Martinez, J. (2013). An Investigation into How EFL Learners Emotionally Respond to Teachers' Oral Corrective Feedback. Colombian Applied Linguistics Journal, 15 (2), 265-278. doi: http://dx.doi.org/10.14483/udistrital .jour.calj.2013.2

Mendez, E., \& Cruz, M. (2012). Teachers' Perception about Oral Corrective Feedback and Their Practice in EFL Classrooms. PROFILE, 14 (2).

Naziri, I., \& Haghverdi, H. (2014). The Effect of Corrective Feedback on Iranian EFL Learners' Pronunciation: The Case of /v/ w/. Indian Journal of Fundamental and Applied Life Science, 4 (4), 925-935. Retrieved from www.cibtech.org/sp.ed/jls/2014/04/j ls.htm.

Pfanner, N. I. (2015). Teacher Corrective Oral Feedback in the Classroom. Journal of Language and Education, 1 (2), 46-55.

Rashidi, A., Basiro, S. R., \& Motlaq, H. S. (2016). The Effect of Corrective Feedback Strategy Types on Iranian EFL Learner's Willingness to Communicate. The Caspian Sea 
Journal, 10 (1), 56-65. Retrieved

from

csjonline.org/CSJ/2016/Supp3/56-

65.pdf

Rezaei, S., Mozaffari, F., \& Hatef, A. (2011).

Corrective feedback in SLA:

Classroom Practice and Future

Directions. International journal of

English Linguistics, 1 (1), 21-29.

doi:

http://dx.doi.org/10.5539/ijel.v1n1p

21

Shabani, K. 92016). The Effect of Immediate and Delayed Error Correction on Accuracy of Iranian EFL Learners' Oral Production. Journal of Studies in Education. 6 (3). DOI: 10.5296/jse.v6i3.8915

Taipale, P. (2012). Oral Errors, Corrective Feedback and Learner Uptake in an EFL Setting. Published Thesis. University of Jyvaskyla. Retrieved from

https://jyx.jyu.fi/dspace/bitstream/h andle/123456789/37544/URN_NBN

_fi_jyu-

201203121409.pdf;sequence $=4$.

Yang, J. (2016). Learners' Oral Corrective Feedback Preferences in Relation to their Cultural Background, Proficiency Level, and Types of Error. System 61. Retrieved from www.elseiver.com/locate/system.

Yin, R. K. (2014). Case Study Research: Design and Methods (5th ed). California: SAGE Publications, Inc.

Zohrabi, K., \& Ehsani, F. (2014). The Role of Implicit and Explicit Corrective Feedback in Persian Speaking EFL Learners' Awareness of and Accuracy in English Grammar. Procedia - Social and Behavioral Sciences 98, 2018-2024. 